SULUH Jurnal Bimbingan Konseling, April 2017, Volume 3 Nomor 2 (36-41)

http://jurnal.umpalangkaraya.ac.id/ejurnal/suluh

\title{
BIMBINGAN KELOMPOK UNTUK MENINGKATKAN MOTIVASI BELAJAR PESERTA DIDIK SMPN 1 SELAT KUALA KAPUAS
}

\author{
Oleh \\ Ni Wayan Ginanti, Asep Solikin, Heru Nurrohman
}

\begin{abstract}
ABSTRAK
Penelitian ini bertujuan (1) Mengetahui profil motivasi belajar peserta didik di SMPN 1 Selat Kuala Kapuas, (2) mengetahui efektifitas program bimbingan kelompok untuk meningkatkan motivasi belajar peserta didik di SMPN 1 Selat Kuala Kapuas. Metode yang di gunakan penelitian adalah menggunakan rancangan penelitian Tindakan kelas Bimbingan dan Konseling ( PTKBK ) yang berusaha memecahkan atau menjawab permasalahan yang dihadapi pada situasi sekarang. Untuk teknik pengumpulan data yang di gunakan adalah observasi dan angket. Sedangkan dalam penelitian ini menggunakan analisis deskriptif dan statistik.

Hasil penelitian ini menunjukan bahwa pemberian layanan bimbingan kelompok dapat meningkatkan motivasi belajar peserta didik. Hal ini dapat di lihat dari penelitian pre test hasil yang di peroleh $64 \%$ dan pada penelitian post test yang diperoleh $95 \%$. Kemudian secara statistik di peroleh harga $\mathrm{P}=000$ yang menunjukan bahwa harga $\mathrm{P}$ jauh lebih kecil dari 0,05. Yang berarti Ho ditolak dan H1 diterima.
\end{abstract}

(C) Universitas Muhammadiyah Palangkaraya

Kata Kunci: Motivasi Belajar, Bimbingan Kelompok.

PENDAHULUAN

Perkembangan zaman karena pengaruh era globalisasi pada masa sekarang sudah sangat jelas dapat kita rasakan terutama bagi masyarakat yang tinggal di daerah perkotaan.Hal tersebut dapat kita lihat dari pola tingkah laku masyarakat, mulai dari segi penampilan, kebutuhan akan barang dan tidak luput juga kebutuhan akan pendidikan.Pada masyarakat perkotaan atau modern pendidikan merupakan sebuah kebutuhan yang sangat signifikan, bahkan sekarang sudah banyak dapat kita temukan warga kita Indonesia yang menempuh pendidikan keluar negeri hanya demi sebuah pendidikan yang dikatakan lebih berkualitas dan tentunya hal tersebut lebih banyak mengeluarkan biaya.

Banyaknya masyarakat Indonesia yang menempuh pendidikan sampai ke luar negeri, hal tersebut bukan berarti pemerintah Indonesia tidak memberi dukungan terhadap pendidikan yang ada di Indonesia. Hal ini terbukti dengan adanya Undang-Undang yang berkaitan dengan pendidikan sebagai bentuk 
keperdulian pemerintah akan kemajuan masyarakatnya dalam dunia pendidikan. Adapun Undang-Undang yang dimaksud adalah UU No. 20 Tahun 2003 pasal 5 Ayat (1) tentang Sistem Pendidikan Nasional, yaitu setiap warga negara mempunyai hak yang sama untuk memperoleh pendidikan yang bermutu.

Pendidikan bermutu dapat diwujudkan dengan berbagai hal yang berkaitan dengan dunia pendidikan yang seluruhnya itu saling berkaitan satu dengan yang lainnya. Berkaitan dengan isi UU di atas, sudah sangat jelas dikatakan bahwa konselor juga digolongkan sebagai pendidik. Dalam hal ini dapat dikatakan bahwa konselor juga memiliki peranan penting dalam memberikan pendidikan yang bermutu bagi peserta didik.

Pendidikan yang bermutu telah ditetapkan oleh pemerintah untuk masyarakatnya, namun dalam penerapannya hal ini harus berjalan secara berdampingan dengan peran pendidik. Hal ini karena, pendidik adalah sosok yang akan berinteraksi langsung dengan peserta didik. Berarti dalam hal ini, seorang pendidik harus benar-benar dapat menentukan pendekatan yang akan digunakan selama proses pembelajaran, metode, media, model, strategi pembelajaran dan lain-lain yang disesuaikan dengan perkembangan anak atau tingkat jenjang pendidikannya yang nantinya dapat meningkatkan mutu pendidikan.

Berbicara mengenai tingkat jenjang pendidikan, yang termasuk salah satu di dalamnya adalah pendidikan SMP (Sekolah Menengah
Pertama). Peserta didik SMP akan mengalami rangkaian perubahan kejasmanian pada dirinya, peserta didik akan berhadapan dengan sejumlah pendidik yang memegang mata pelajaran tertentu dengan gaya mengajar dan karakter kepribadian yang berbedabeda. Selain itu,di SMP peserta didik juga akan mempelajari lebih banyak mata pelajaran yang lebih sulit dari SD. Apa yang dihadapi oleh peserta didik di SMP pada umumnya tersebut, tentunya akan mempengaruhi motivasi untuk mendapatkan prestasi dalam kegiatan belajar.

Mc. Donald (Sardiman 2007: 73) motivasi adalah perubahan energi dalam diri seseorang yang ditandai dengan munculnya "feeling" dan didahului dengan tanggapan adanya tujuan. Hull (Dimyati dan Mudjiono, 2009: 82) yaitu dorongan atau motivasi berkembang untuk memenuhi kebutuhan organisme. Donald (Nashar, 2004:39), motivasi belajar adalah suatu perubahan tenaga di dalam diri seseorang (pribadi) yang ditandai dengan timbulnya perasaan dan reaksi untuk mencapai tujuan

$$
\text { Indikator motivasi belajar }
$$
menurut Uno (2009 : 23) dapat diklasifikasikan sebagai berikut: 1) Adanya hasrat dan keinginan berhasil, 2) Adanya dorongan dan kebutuhan dalam belajar, 3) Adanya harapan dan cita-cita masa depan, 4) Adanya penghargaan dalam belajar, 5) Adanya kegiatan yang menarik dalam belajar, 6) Adanya lingkungan belajar yang kondusif sehingga memungkinkan seseorang siswa dapat belajar dengan baik. 
Motivasi agar mendapatkan prestasi dalam belajar, dipengaruhi oleh dua faktor yaitu faktor internal (dari dalam diri individuitu sendiri) dan eksternal (dari luar diri individu itu sendiri), dimana kedua hal tersebut harus seimbang. Walaupun dengan vasilitas belajar yang kurang, apabila anak tersebut memiliki motivasi belajar yang baik maka dia masih mampu menerima materi yang diajarkan, dan sebaliknya, sebagus apapun vasilitas yang diberikan, apabila dari dalam diri anak tidak ada motivasi untuk belajar maka prestasi anakakanrendah. Oleh karena itu harus ada kerjasama yang baik dari semua pihak sekolah terutama dengan guru BK (Bimbingan dan Konseling) agar mampu membangkitkan motivasi belajar peserta didik.

Berdasarkan hasil pengamatan peneliti yang dilakukan di SMPN 1 Selat Kapuas pada kelas VIII diketahui bahwa motivasi belajar peserta didik masih rendah.Hal tersebut terlihat ketika proses belajar mengajar peserta didik cepat bosan, peserta didik sering terlihat mengantuk didalam kelas,sering keluar masuk kelas dengan alasan kekamar kecil, terlambat mengumpulkan tugas, datang terlambat, mengeluh jika diberi tugas yang berat, Terkadang peserta didik sibuk bermain sendiri atau bercanda dengan temannya, bahkan cenderung diam ketika guru menanyakan kembali materi yang telah disampaikan, Peserta didik pun tidak mau bertanya walaupun peserta didik tersebut tidak mengerti, mereka lebih baik diam seolah-olah sudah paham dengan materi yang disampaikan.
Kondisi tersebut apabila dibiarkan maka akan memicu munculnya masalah, sehingga memerlukan layanan yang sesuai. Salah satu layanan yang ada dalam BK yaitu bimbingan kelompok.

Gibson dan Mitchell (2011), yang mengatakan bahwa istilah bimbingan kelompok mengacu kepada aktivitasaktivitas kelompok yang berfokus kepada penyediaan informasi atau pengalaman lewat aktivitasyang terencana dan terorganisasi. Hartinah (2009: 4-5) mengemukakan bimbingan kelompok adalah :Teknik pendekatan secara kelompok, yaitu bimbingan yang dilaksanakan secara kelompok terhadap sejumlah individu sekaligus sehingga beberapa orang atau individu sekaligus dapat menerima bimbingan yang dimaksudkan. Rusmana (Nurnaningsih,2011: mengemukakan bahwa bimbingan kelompok dapat didefinisi-kan sebagai suatu proses pemberian bantuan kepada individu melalui suasana kelompok yang memingkinkan setiap anggota untuk belajar berpartisipasi aktif dan berbagi pengalaman dalam upaya pengembangan wawasan, sikap atau keterampilan yang diperlukan dalam upaya mencegah timbulnya masalah atau upaya pengembangan pribadi. Romlah (2001: 3) mengemukakan definisi bimbingan kelompok adalah proses pemberian bantuan yang diberikan pada individu dalam situasi kelompok.

Berdasarkan uraian di atas, peneliti merasa tertarik untuk mengadakan penelitian tentang Bimbingan Kelompok untuk 
Meningkatkan Motivasi Belajar Peserta Didik SMPN 1 SelatKuala Kapuas.

\section{METODE PENELITIAN}

Jenis penelitian yang akan digunakan dalam penelitian ini adalah PTBK (Penelitian Tindakan dalam Bimbingan Konseling). Diknas (Badrujaman, 2012 :12), Penelitian Tindakan dalam Bimbingan Konseling (PTBK) merupakan salah satu strategi yang memanfaatkan tindakan nyata dalam proses pengembangan keputusan memperlajarisutau masalah, mencari solusi serta melakukan perbaikan atas suatu program sekolah atau kelas khusus. Subjek Penelitian Tindakan dalamBimbingan Konseling (PTBK) ini adalah peserta didik kelas VIII SMPN 1 Selat Kuala Kapuas yang berjumlah 96 orang. Adapun model kerja dalam bentuk dua siklus, dengan diagram siklus sebagai berikut.

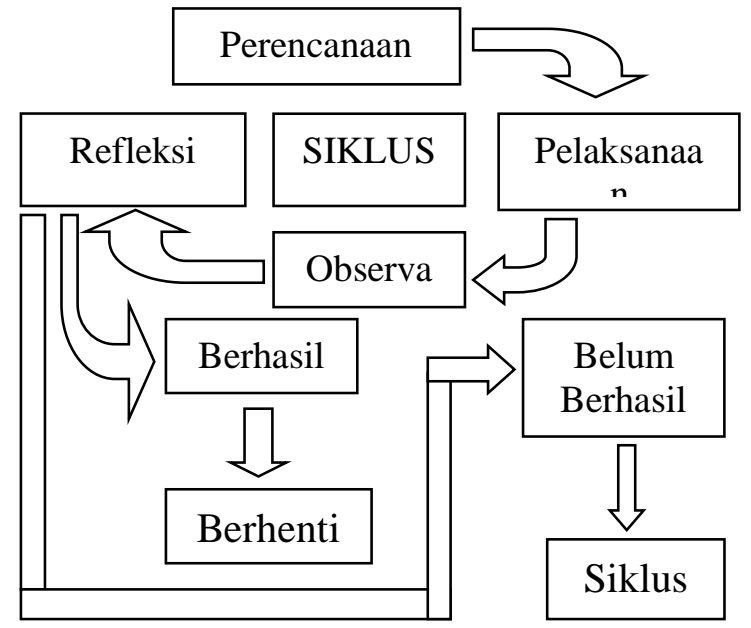

Instrument penelitian yang digunakan yaitu skala, lembar observasi dokumentasi. Sugiyono(2013: 167) mengatakan bahwa skala pengukuran merupakan kesepakatan yang digunakan sebagai acuan untuk menentukan panjang pendeknya interval yang ada dalam alat ukur, sehingga bila alat ukur tersebut digunakan dalam pengukuran, akan menghasilkan data kuantitatif .

\section{HASIL DA PEMBAHASAN}

Hasil layanan bimbingan kelompok yang diberikan kepada 6 orang peserta didik kelas VIII di SMPN 1Selat Kuala Kapuas untuk membantu peserta didik menyelesaikan masalah motivasi belajar, bimbingan kelompok yang diberikan melalui 3 sesibimbingan kelompok siklus I. Hal ini terlihat pada (I) indikator tekun menghadapi tugas sebelum diberikan layanan bimbingan kelompok 90\% pada sedang. Setelah diberikan layanan bimbingan kelompok meningkat pada skor 99\% (2)Indikator ulet menghadapi kesulitan yang dilakukan sebelum diberikan layanan bimbingan kelompok $89 \%$ pada kategori sedang, setelah diberikan layanan bimbingan kelompok meningkat pada $100 \%$. (3) indikator menunjukkan minat terhadap macammacam masalah sebelum diberikan layanan bimbingan kelompok $56 \%$ pada katagorisedang, setelah diberikan layanan bimbingan kelompok meningkat pada $100 \%$ (4) indikator lebih senang bekerja sendiri sebelum diberikan layanan bimbingan kelompok 90\% pada kategori sedang, setelah diberikan layanan bimbingan kelompok meningkat pada 100\%,(5) indikator cepat bosan pada tugas-tugas yang rutin sebelum diberikan layanan bimbingan kelompok 86\%pada katagori rendah, setelah diberikanlayanan bimbingan kelompok meningkat pada skor $100 \%$, (6) indikator dapat mempertahankan 
pendapatnya sebelum diberikan layanan bimbingan kelompok 79\% pada kategori rendah, setelah diberikan layanan bimbingan kelompok meningkat pada skor 100\%, (7) indikator tidak mudah melepaskan hal yang diyakini sebelum diberikan layanan bimbingan kelompok $78 \%$ pada kategori rendah, setelah diberikan layanan bimbingan kelompok meningkat pada skor 100\%, (8) indikator senang mencari dan memecahkan masalah soal-soal sebelum diberikan layanan bimbingan kelompok 78\% pada kategori rendah, setelah diberikan layanan bimbingan kelompok meningkat pada skor $100 \%$.

Tabel 1

\begin{tabular}{lll}
\multicolumn{3}{c}{ Peningkatan } \\
\hline Subjek & Pretes & Postes \\
\hline ADS & 83 & 112 \\
CTW & 88 & 100 \\
YHK & 86 & 107 \\
FE & 85 & 106 \\
SN & 81 & 125 \\
AN & 76 & 127 \\
\hline
\end{tabular}

Dengan demikian dapat diketahui bahwa upaya untuk meningkatkan motivasi belajar peserta didik dapat diupayakan dengan layananbimbingan kelompok.Hasil ini terlihat setelah siklus I dilaksanakan.Peserta didik menunjukkan perkembangan yang baik, terlihat beberapa peserta didik sudah berani berpendapat, berkonsentrasi, memperhatikan guru menjelaskan, mau bertanya, dan lebih rajin dalam mengerjakan tugas-tugas yang diberikan setelah diberikan layanan bimbingan kelompok.Berdasarkan data yang sudah dipaparkan di atas dapat dikatakan bahwa dalam penelitian ini berhasil dilaksanakan, setelah dilakukan layanan bimbingan kelompok untuk meningkatkan motivasi belajar 6 orang peserta didik tersebut menjadi meningkat dengan persentase $100 \%$ .maka tidak perlu untuk dilakukan tindakan lebih lanjut/siklus II.

\section{KESIMPULAN}

Berdasarkan Motivasi Belajar peserta didik kelas VIII di SMPN 1 Selat Kuala Kapuas setelah diberikan layanan Bimbingan Kelompok. Berdasarkan hasil posttest,secara umum rata-rata motivasi belajar peserta didik setelah diberi layanan bimbingan kelompok naik sebesar 190.63. Setelah diadakan

ujiefektivitasmodeldiketahuibahwaterhit ung $=-8.638$. Jika nilai $p$ adalah 000 dan nilai

$\mathrm{s}=$ adalah $0,05 \mathrm{maka} 0,007<0,05$ yangberar ti mendekati nilai 0sehinggasignifikan ataunilai $p<$ nilai sehingga hipotesis Ho ditolak dan H1diterima atau sama dengan H1: $t \quad \mu$ sebelum $<\mu$ sesudah.. Penolakan Ho berarti ada perbedaan antara rata- rata tingkat motivasi belajar dari hasil Pretest dan Posttest, sehingga dapat disimpulkan bahwa layanan bimbingan kelompok efektif untuk meningkatkan motivasi belajar peserta didik.

\section{DAFTAR PUSTAKA}

Badrujaman. 2012. Penelitian tindakan bimbingan konseling. Jakarta: indeks 
Dimyati, mudjiono. 2009. Belajar dan pembelajaran. Jakarta: Rieneka cipta

Gibson R.L dan M.H mitchell. 2011. Bimbingan dan konseling. Yogyakarta: pustaka pelajar

Hamzah uno. 2009. Teori motivasi dan pengukuranya. Jakarta: bumi aksara

Hartinah sitti. 2009. Konsep dasar Bimbingan kelompok. Bandung: PT refika aditama

Nashar. 2004. Peran motivasi dan kemampuan awal dalam kegiatan pembelajaran. jakarta: Delia press

Nurnaningsih. 2011. Bimbingan kelompok untuk meningkatkan kecerdasan emosional siswa. Jurnal BK UPI edisi Khusus no 1 agustus 2011. Issn:1412-565x

Sardiman. 2007. Interaksi dan motivasi belajar mengajar. Bandung: rajawali pers

Tatik romlah. 2001. Teori dan praktik bimbingan kelompok. Malang: UM Press 